\title{
ANALISIS KESIAPAN PENGIMPLEMENTASIAN EDUROAM DI UIN SUNAN KALIJAGA
}

\author{
Maria Ulfah Siregar ${ }^{1}$, Alifah Amalia ${ }^{2}$, Bambang Sugiantoro $^{3}$ \\ ${ }^{1,3}$ Magister Informatika, Fakultas Sains dan Teknologi, Universitas Islam Negeri Sunan Kalijaga \\ ${ }^{2}$ Program Studi Matematika, Fakultas Sains dan Teknologi, Universitas Islam Negeri Sunan Kalijaga \\ 1'ulfahtc96@yahoo.com, ${ }^{3}$ bambang.sugiantoro@uin-suka.ac.id
}

\begin{abstract}
This research is based on the existence of Eduroam in academia world which offers the easiness on managing data through internet. Inevitably, UIN Sunan Kalijaga as one of big campus in terms of number of population of academicians and the usage of internet in its area, has not joined in a group of institutions that implemented Eduroam. Through this research we aim to give brainstorming to academicians of UIN Sunan Kalijaga of the existence of Eduroam, then we will conclude the feasibility of implementing Eduroam on UIN Sunan Kalijaga. As guidances for this research are two hypotheses that we built. Our research method is conducting survey and interview to two domestic institutions which implemented Eduroam. It is followed by distributing online internal questionnare in UIN Sunan Kalijaga to do the brainstorming and collecting data. These data then were analyzed statistically to get the descriptive statistic, correlation and proved the hypotheses. Based on our analysis, it is found that there is a strong relation between the knowledge of Eduroam and the intention to join Eduroam, and a strong relation between the frequency of the usage of internet and the intention to join Eduroam. Therefore, we claim that it is feasible to implement Eduroam on UIN Sunan Kalijaga, by first improving the quality and quantity of the internet connection facilities on UIN Sunan Kalijaga.
\end{abstract}

Keywords: Eduroam, Descriptive Statistic, Correlation and Coeficient of Correlation, Validity and Reliability Tests

\begin{abstract}
ABSTRAK
Penelitian ini dilatarbelakangi oleh eksistensi Eduroam di dunia akademis yang bisa memberikan berbagai kemudahan dalam pengelolaan data melalui jaringan internet. Di sisi lain, UIN Sunan Kalijaga sebagai kampus yang cukup besar populasi sivitas akademika dan penggunaan internet di dalam wilayahnya, masih belum bergabung dengan institusi-institusi lain yang mengimplementasikan Eduroam. Melalui penelitian ini kami bermaksud memberikan pencerahan kepada sivitas akademika UIN Sunan Kalijaga akan keberadaan Eduroam yang selanjutnya menentukan kelayakan Eduroam diimplementasikan di UIN Sunan Kalijaga. Kami menyusun dua hipotesis untuk mengarahkan penelitian ini. Metode penelitian kami adalah dengan melakukan survei dan wawancara ke dua insitusi pendidikan dalam negeri yang mengimplementasikan Eduroam. Kemudian kami menyebarkan kuisoner internal di UIN Sunan Kalijaga secara online untuk melakukan brainstorming dan pengumpulan data. Data yang diperoleh kemudian dianalisis secara statistik untuk melihat statistika deskriptif, korelasi dan pengujian hipotesis. Berdasarkan analisis statistik, diperoleh bahwa adanya hubungan yang kuat antara pengetahuan mengenai Eduroam dengan keinginan bergabung dengan Eduroam, dan hubungan yang kuat juga antara frekuensi penggunaan internet dengan keinginan bergabung dengan Eduroam. Sehingga, kami menyimpulkan bahwa adalah layak untuk mengimplementasikan Eduroam di UIN Sunan Kalijaga, dengan meningkatkan kualitas dan kuantitas fasilitas koneksi internet di UIN Sunan Kalijaga.
\end{abstract}

Kata Kunci: Eduroam, Statistika Deskriptif, Korelasi dan Koefisien Korelasi, Uji Validitas dan Reliabilitas 


\section{PENDAHULUAN}

Kecenderungan di dunia akademis dan riset saat ini adalah bertambah mobile-nya para peneliti dan pelajar, sehingga keinginan untuk melayani tamu-tamu akademis dengan akses Wi-Fi (Wireless Fidelity) yang aman bisa menimbulkan permasalahan administrasi yang tidak sederhana. Sumberdaya harus dialokasikan untuk menyediakan dan mendukung akun sementara yang berbasis orang per orang (hal ini menjadi sangat mahal untuk kampus yang besar). Walaupun kegiatan tersebut berubah setiap hari, akun-akun tamu ini dapat menyebabkan isu dalam pengauditan disebabkan banyak pengguna berbagi akun yang sama sehingga menyulitkan pelacakan penggunaan web yang tidak semestinya.

Eduroam [1] (education roaming), dengan logo ditunjukkan pada Gambar 1, adalah layanan akses yang aman dan mendunia yang dikembangkan bagi komunitas riset dan pendidikan internasional. Layanan ini yang bermula di Eropa yaitu di Belanda pada tahun 2003 [2], sekarang ini telah mencapai momentumnya melalui komunitas riset dan pendidikan yang tersedia di 72 wilayah dari kampus-kampus sampai kedai kopi-kedai kopi.

Inisiatif Eduroam yang dimulai tahun 2003 termasuk di dalam task force TERENA yang mendemonstrasikan kemungkinan menggabungkan infrastruktur yang berbasiskan pada RADIUS dengan teknologi IEEE 802.1X untuk menghasilkan akses jaringan roaming pada jaringan peneliti dan pendidikan. RADIUS adalah teknik pengamanan yang banyak digunakan untuk sistem otentikasi pada jaringan wireless [3]. Berdasarkan penelitian [3], sistem otentikasi RADIUS masih rentan terhadap penyelusupan. Untuk memperbaikinya, bisa dikembangkan sistem lainnya sebagai pendukung RADIUS, yaitu sistem yang berbasis EAP-TLS.

Pengujian awal Eduroam dilaksanakan di lima institusi yang berlokasi di Belanda, Finlandia, Portugal, Kroasia dan Inggris. Negara di luar Eropa yang pertama bergabung dengan Eduroam adalah Australia pada Desember 2004 [4].

Tahun 2016 adalah tahun berikutnya yang mengalami pertumbuhan dan pengembangan Eduroam dengan $23 \%$ peningkatan pada otentikasi internasional dan $26 \%$ peningkatan otentikasi nasional. Sekarang ini terdapat 85 negara berpartisipasi dalam Eduroam di seluruh dunia dengan Tajikistan menjadi negara yang terakhir bergabung dalam keluarga Eduroam.

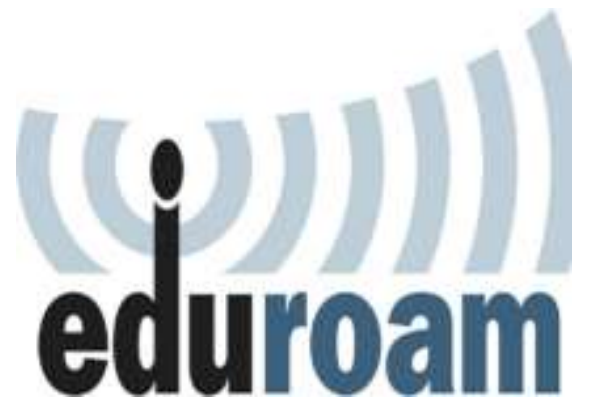

Gambar 1. Logo Eduroam [1]

Sistem AuthN Eduroam tercatat melebihi 2,6 juta otentikasi nasional (yang pengguna dari institusi lain di dalam negara yang sama mengotentikasi Wi-Fi mereka melalui Eduroam) dan lebih dari 592 juta otentikasi internasional. Dengan menyediakan akses WiFi yang gratis dan aman di lokasi partisipan bagi berjuta-juta pelajar, peneliti, dan staf akademik di seluruh dunia, Eduroam secara berkelanjutan menjadi tangguh.

Eduroam mengizinkan para pelajar, peneliti dan staf dari institusi-institusi yang menggunakan Eduroam terhubung dengan koneksi Internet di lingkungan kampus dan juga ketika mengunjungi institusi-institusi pengguna Eduroam lainnya, dengan cara yang sederhana saja yaitu dengan membuka laptop mereka.

Eduroam didasarkan pada enkripsi yang paling aman dan standard otentikasi yang eksis saat ini. Keamanannya melebihi keamanan dari hotspot komersial yang umum saat ini.

Berdasarkan uraian di atas, ketersediaan Eduroam di suatu perguruan tinggi memberikan kemudahan bagi sivitas akademika di perguruan tinggi tersebut melakukan koneksi Internet. Hal ini menyebabkan kegiatan pengajaran, penelitian dan pengabdian kepada masyarakat menjadi lebih mudah untuk diupdate. Kolaborasi dengan peneliti-peneliti di dalam perguruan tinggi yang sama, di dalam negeri dan di luar negeri menjadi lebih mudah dilakukan. Sehingga ketersediaan Eduroam di suatu institusi perguruan tinggi tidak dapat dihindari memudahkan jalan institusi tersebut menjadi kampus yang berbasiskan pada riset.

Penelitian yang dilakukan oleh Adisti [5] mendapatkan hubungan yang kuat antara pemanfaatan teknologi Wi-Fi terhadap tingkat kunjung pemustaka di UPT Perpustakaan Politeknik Negeri Semarang. Penelitian lainnya 
oleh Jelita [6] mendapatkan bahwa penggunaan Wi-Fi dapat meningkatkan indeks prestasi mahasiswa. Walaupun demikian, jika teknologi Wi-Fi dikelola dengan menggunakan Eduroam, manfaat yang diperoleh akan lebih besar.

Pengelolaan Wi-Fi, sebagai bagian dari pengelolaan teknologi informasi, perlu disesuaikan dengan kepentingan bisnis dan kemanfaatan bagi pengguna layanan. Ini sesuai dengan yang disampaikan oleh Blokdijk dalam [7] yaitu mengenai ITSM (Information Technology Service Management).

Tetapi sayangnya, UIN Sunan Kalijaga belum bergabung menjadi salah satu institusi yang berpartisipasi di dalam Eduroam. Padahal di satu sisi, UIN Sunan Kalijaga berkeinginan menjadi kampus yang berbasis riset. UIN Sunan Kalijaga pun banyak menerima tamu-tamu akademik dari luar negeri.

Berdasarkan latar belakang di atas, pada penelitian ini kami rumuskan masalah yang hendak kami teliti:

1. Adakah hubungan antara pengetahuan mengenai Eduroam dengan keinginan menjadikan UIN Sunan Kalijaga sebagai salah satu institusi yang bergabung dengan Eduroam?

2. Adakah hubungan antara frekuensi penggunaan internet dengan menjadikan UIN Sunan Kalijaga sebagai salah satu institusi yang bergabung Eduroam?

Oleh karena itu, penelitian kami bertujuan untuk melakukan observasi atas pengetahuan mengenai Eduroam di kalangan sivitas akademika di UIN Sunan Kalijaga, dan penggunaan internet di kalangan sivitas akademika di UIN Sunan Kalijaga. Selanjutnya adalah menghubungkan kedua temuan tersebut dengan menganalisis kesiapan UIN Sunan Kalijaga bergabung dengan Eduroam.

Penelitian mengenai Eduroam ini, sejauh yang kami ketahui, adalah yang pertama dilakukan di UIN Sunan Kalijaga. Teknologi Eduroam juga, sepanjang yang kami ketahui, belum dikenal secara meluas di UIN Sunan Kalijaga. Biasanya yang mengenal Eduroam adalah sivitas akademika UIN Sunan Kalijaga yang pernah menggunakannya, baik selama studi di luar negeri atau kampus-kampus di dalam negeri yang sudah bergabung dengan Eduroam, atau melakukan kunjungan ke luar negeri, atau pihak-pihak yang terkait dengan pengelolaan teknologi informasi. Kutipankutipan pada sumber berkaitan telah kami tandai dengan memberikan sitasi pada bagianbagian tersebut di tempat-tempat yang berkenaan. Penelitian ini didanai oleh lembaga penelitian di UIN Sunan Kalijaga. Naskah ini adalah hasil asli dari penelitian kami menggunakan ide peneliti sendiri.

\section{METODOLOGI}

Penelitian ini bersifat kuantitatif. Kami menggunakan metode survei dan interview, serta kuisoner.

Survei ditujukan untuk mencari informasi mengenai manfaat menggunakan Eduroam dan hal yang berkenaan dengan instalasi Eduroam. Kami melakukan survei ke beberapa institusi partisipan Eduroam dalam negeri.

Sementara metode kuisoner ditujukan untuk melakukan brainstorming Eduroam di kalangan sivitas akademisi UIN Sunan Kalijaga. Dalam hal ini yaitu mengenalkan teknologi Eduroam ke sivitas akademisi UIN Sunan Kalijaga.

Setelah kedua metode di atas dilakukan, informasi yang didapat akan diolah menggunakan statistika deskriptif dan analisis korelasi untuk melihat gambaran awal dari kelayakan implementasi Eduroam di UIN Sunan Kalijaga. Dalam menganalisis data, kami menggunakan bantuan software SPSS dan juga Excel.

Selanjutnya kami merumuskan hipotesis penelitian sebagai berikut:

H1: Adanya pengaruh positif antara pengetahuan mengenai Eduroam dengan keinginan bergabung dengan jaringan Eduroam

H2: Adanya pengaruh positif antara penggunaan internet dengan keinginan bergabung dengan jaringan Eduroam

\section{HASIL DAN PEMBAHASAN}

Berdasarkan interview yang telah kami lakukan, informasi yang diperoleh adalah tidak adanya biaya untuk mengimplementasikan Eduroam. Biaya yang ada hanyalah untuk penyediaan infrastruktur, training bagi teknisi, serta pemeliharaan. Dalam pengimplementasian Eduroam, terdapat dua institusi yang bekerjasama, yaitu Home Institution (institusi yang diletakkan akun 
Eduroam) dan Visited Institution (institusi dari person yang bertamu ke Home Institution).

Eduroam di Indonesia dibagi ke dalam dua wilayah. Institusi-institusi pendidikan tinggi atau riset yang terletak di bagian barat Indonesia, seperti Jawa Barat, Sumatera, Jakarta dan Kalimantan hanya akan dilayani oleh Federation Level RADIUS (FLR) level yang pertama [8]. Sementara itu, bagi institusi yang terletak di bagian timur Indonesia, misalnya Jawa Tengah, Yogyakarta, Jawa Timur, Bali, Nusa Tenggara, Sulawesi, Maluku dan Papua Barat, hanya akan dilayani oleh FLR level yang kedua. Kedua FLR 1 dan FLR 2 memelihara data yang sama dalam penanganan setiap “.id” wilayah yang di-passing-kan dari/ menuju level teratas Eduroam. Pembagian ini ditunjukkan pada Gambar 2.

Seperti yang telah disebutkan di atas, berdasarkan kesepakatan antara ITB dan UII, maka ITB dipercayakan untuk mengkoordinir daerah wilayah barat Indonesia, sedangkan UII untuk wilayah timur Indonesia. Yogyakarta adalah termasuk dalam wilayah timur Indonesia.

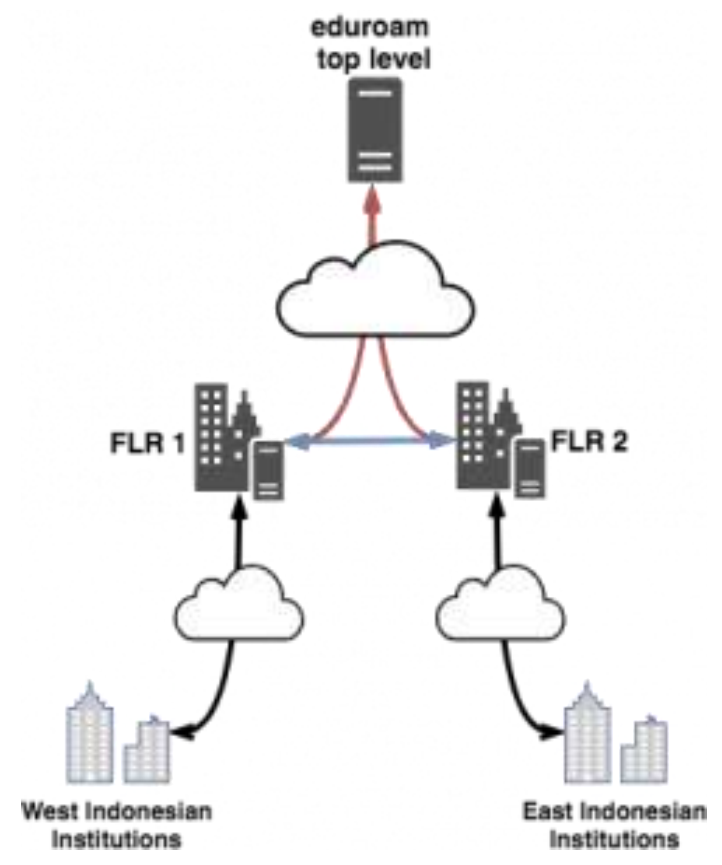

Gambar 2. Topologi Eduroam di Indonesia [8]

Sebagaimana informasi yang kami peroleh dari interview kedua, tidak semua penyedia jasa internet di Indonesia mengetahui Eduroam. Berdasarkan informasi tersebut, keberadaan Eduroam yang belum meluas di Indonesia bisa dipahami.
Berikut sedikit deskripsi mengenai Eduroam. Bergantung pada kebijakan lokal institusi yang dikunjungi, partisipan Eduroam bisa saja memiliki sumberdaya tambahan. Sumberdaya tambahan bisa berbeda-beda antara satu institusi dengan institusi lainnya.

Mengenai kerahasian data pengguna, credential pengguna terjaga aman karena Eduroam tidak membagikannya dengan daerah yang dikunjungi pengguna. Sebagai gantinya, credential pengguna di-forward ke institusi asal pengguna, sehingga credential mereka dapat diverifikasi dan divalidasi.

Hal ini dikarenakan, sistem menggunakan suatu jaringan server yang dijalankan oleh institusi, dan jaringan penelitian serta pendidikan nasional yang berpartisipasi (NRENS) untuk me-route dengan aman permintaan-permintaan tersebut kembali ke institusi asal pengguna. Eduroam menyediakan akses jaringan yang terotentikasi pada lokasi mana saja yang layanan ini diizinkan. Setiap organisasi-organisasi partisipan yang menawarkan akses jaringan kepada pengguna terotentikasi adalah mampu menggunakan kebijakan filterisasinya sepanjang hal ini memberikan informasi yang jelas kepada pengguna mengenai aturan-aturan pemfilteran. Oleh karena itu, alasan keamanan data dalam Eduroam tidak perlu diragukan.

Berdasarkan penelitian Ghaisani [9] yang mengutip States of Internet (penelitian oleh Akamai Tehcnologies Inc. pada kuartal III 2014), kecepatan koneksi internet di Indonesia menempati peringkat kedua terendah se-Asia Pasifik yaitu dengan kecepatan rata-rata 1,5 Mbps, sementara di dunia menempati peringkat 118. Hal ini jugalah yang menyebabkan Eduroam belum dikenal luas di Indonesia diakibatkan kurang memuaskannya kualitas jaringan internet di Indonesia.

Selanjutnya kami mendesain kuisoner. Dalam mendesain kuisoner ini kami melakukan studi literatur berkaitan tipe penelitian yang bersesuaian dengan penelitian kami. Kami menggunakan Model Penerimaan Teknologi (Technology Acceptance Model) dari Davis, Bogozzi, dan Warshaw [10][11]. Kuisoner ini kami sebarkan secara online di internal UIN Sunan Kalijaga, melalui akun media sosial yang dimiliki oleh peneliti. Bentuk pertanyaan dalam kuisoner ini adalah pertanyaan yang mengumpulkan informasi mengenai hubungan dan deskripsi [12] dari responden dengan objek kajian yaitu penggunaan internet dan Eduroam 
di UIN Sunan Kalijaga. Kami mengadaptasi kuisoner dari Nurhidayat [13] dalam penyusunan butir-butir pertanyaan dalam angket/ kuisoner penelitian kami.

Terdapat lima kelompok/ kelas pertanyaan dalam kuisoner tersebut: I. Data Diri (3 butir pertanyaan), II. Perceived Usefulness (5 butir pertanyaan), III. Perceived Ease of Use (3 butir pertanyaan), IV. Behavioral Intention (13 butir pertanyaan), dan V. Usage Intention (13 butir pertanyaan). Kelas pertanyaan kedua sampai terakhir memiliki pilihan jawaban: Sangat Setuju, Setuju, Netral, Tidak Setuju, Sangat Tidak Setuju. Kami menyimbolkan pilihan jawaban tersebut sebagai berikut: 5, 4, 3, 2, dan 1 , sesuai urutan pilihan jawaban. Pertanyaanpertanyaan ini secara umum mendukung efektivitas dan efisiensi yang lebih mudah dicapai jika pengelolaan teknologi informasi di suatu institusi adalah berjalan dengan baik [14].

Jumlah responden yang kami peroleh adalah 66 orang yang terdiri dari mahasiswa, dosen, dan tenaga tendik. Kami tidak melakukan sampling untuk pemilihan responden. Hal ini karena waktu penelitian yang tidak lama, sehingga kami menerapkan fast response, yang berarti respon tercepat dalam menanggapi kuisoner inilah yang kami ambil sebagai responden.

Walaupun jumlah responden ini sangat sedikit dibandingkan jumlah sivitas akademika di UIN Sunan Kalijaga, kami berharap, hasil analisis yang kami lakukan bisa merepresentasikan keadaan di UIN Sunan Kalijaga. Tabel 1-3 menunjukkan data diri responden. Dalam penelitian ini kami hanya mengumpulkan data diri: jenis kelamin, jenis pekerjaan dan jenis pendidikan terakhir dari setiap responden.

Tabel 1. Komposisi responden berdasarkan jenis kelamin.

\begin{tabular}{|c|c|c|}
\hline Jenis Kelamin & Laki-laki & Perempuan \\
\hline $\begin{array}{l}\text { Jumlah (dalam } \\
\%)\end{array}$ & 67 & 33 \\
\hline
\end{tabular}

Tabel 2. Komposisi responden berdasarkan jenis pekerjaan.

\begin{tabular}{|c|c|c|c|}
\hline Jenis Pekerjaan & Mhs & Dosen & Tendik \\
\hline $\begin{array}{l}\text { Jumlah (dalam } \\
\%)\end{array}$ & 85 & 12 & 3 \\
\hline
\end{tabular}

Tabel 3. Komposisi responden berdasarkan jenis pendidikan terakhir.

\begin{tabular}{lcccc}
\hline Pendidikan Terakhir & SMA & S1 & S2 & S3 \\
\hline Jumlah (dalam \%) & 65 & 18 & 11 & 6 \\
\hline
\end{tabular}

Berdasarkan uji validitas dan reliabilitas kuisoner, semua butir pertanyaan adalah valid. Ini berarti bahwa ada keterhubungan antara butir-butir pertanyan di dalam suatu kelas pertanyaan.

Kami berikan uji validitas untuk kelas pertanyaan Perceived Usefulness (atau kelas I) yang ditunjukkan pada Tabel 4.

Tabel 4. Rekapitulasi uji validitas.

\begin{tabular}{|c|c|c|}
\hline Variabel & $\begin{array}{c}\text { Nilai } \\
\text { Korelasi }\end{array}$ & Keterangan \\
\hline $\begin{array}{l}\text { Dengan menggunakan } \\
\text { hotspot publik untuk } \\
\text { mengakses internet di } \\
\text { UIN Sunan Kalijaga, } \\
\text { tugas kuliah/ pekerjaan } \\
\text { adalah mudah saya } \\
\text { kerjakan. }\end{array}$ & 0,896 & Valid \\
\hline $\begin{array}{l}\text { Dengan menggunakan } \\
\text { hotspot publik untuk } \\
\text { mengakses internet di } \\
\text { UIN Sunan Kalijaga, } \\
\text { penyelesaian tugas } \\
\text { kuliah/ pekerjaan dapat } \\
\text { saya percepat. }\end{array}$ & 0,916 & Valid \\
\hline $\begin{array}{l}\text { Dengan menggunakan } \\
\text { hotspot publik untuk } \\
\text { mengakses internet di } \\
\text { UIN Sunan Kalijaga, } \\
\text { kualitas pekerjaam/ } \\
\text { pengerjaan tugas kuliah } \\
\text { dapat saya tingkatkan. }\end{array}$ & 0,935 & Valid \\
\hline $\begin{array}{l}\text { Dengan menggunakan } \\
\text { hotspot publik untuk } \\
\text { mengakses internet di } \\
\text { UIN Sunan Kalijaga, } \\
\text { pekerjaan/ pengerjaan } \\
\text { tugas adalah mudah } \\
\text { saya kontrol. }\end{array}$ & 0,875 & Valid \\
\hline $\begin{array}{l}\text { Dengan menggunakan } \\
\text { hotspot publik untuk } \\
\text { mengakses internet di } \\
\text { UIN Sunan Kalijaga, } \\
\text { efektivitas kerja dapat } \\
\text { saya tingkatkan. }\end{array}$ & 0,950 & Valid \\
\hline
\end{tabular}

Selanjutnya, nilai koefisien Cronbach's Alpha pada kelas pertanyaan ini adalah 0.951 (bisa dilihat pada Tabel 5) yang lebih besar dari 0.242 , sehingga instrumen kelas ini dinyatakan 
reliabel. Ini bermaksud, instrumen ini handal untuk digunakan. Rumus dari nilai koefisien Cronbach's Alpha adalah:

$$
r_{i}=\frac{k}{k-1}\left(1-\frac{\sum \sigma_{i}{ }^{2}}{\sigma^{2}}\right)
$$

$$
\begin{aligned}
& \text { Keterangan: } \\
& \begin{array}{ll}
r_{i} & =\text { koefisien Cronbach's Alpha } \\
k & =\text { jumlah butir pertanyaan } \\
\sigma_{i}{ }^{2} & =\text { ragam butir pertanyaan } \\
\sigma^{2} & =\text { jumlah total }
\end{array}
\end{aligned}
$$

Jika koefisien Cronbach's Alpha $r_{i} \geq$ nilai $r_{\text {tabel }}$ maka dapat dinyatakan instrumen tes yang diujicobakan reliabel [15].

Tabel 5. Koefisien cronbach's alpha.

$\begin{array}{r}\begin{array}{c}\text { Cronbach's } \\ \text { Alpha }\end{array} \\ \hline, 951 \\ \hline\end{array}$

Uji validitas dan reliabilitas dilakukan untuk mengukur kualitas data yang ditentukan oleh masing-masing butir pertanyaan. Bisa dikatakan bahwa uji validitas dilakukan untuk mengetahui apakah butir-butir pertanyaan yang berfungsi sebagai alat ukur dapat digunakan untuk mengukur data secara tepat (kemampuan dari angket kuisoner untuk mengukur objek) [16]. Pengujian dilakukan dengan menggunakan uji korelasi Product Moment Pearson. Jika nilai koefisien korelasi $\left(r_{\text {hitung }}\right)>$ $r_{\text {tabel }}$ dengan derajat bebas $n-2$, maka dapat dinyatakan variabel yang diujicobakan adalah valid. Rumus untuk menghitung nilai koefisien korelasi adalah sebagai berikut:

$$
r=\frac{n \sum x y-\sum x \sum y}{\sqrt{\left\{n \sum x^{2}-\left(\sum x\right)^{2}\right\}\left\{n \sum y^{2}-\left(\sum y\right)^{2}\right\}}}
$$

\footnotetext{
Keterangan:

$r=$ koefisien antara variabel $x$ dan $y$

$x=$ skor pertanyaan untuk setiap subjek

$y=$ skor total

$x y=$ skor pertanyaan dan skor total

$n=$ jumlah sampel
}

Korelasi adalah suatu metode statistika untuk mengetahui hubungan linier antara suatu variabel dengan variabel yang lain, bisa dua atau lebih variabel [17]. Sehingga analisa ini bisa digunakan untuk melihat sejauh mana perubahan pada suatu data berhubungan dengan perubahan data yang lain [18].

Analisis ini ditemukan oleh Karl Pearson pada awal 1900, sehingga dikenal dengan sebutan Korelasi Product Moment Pearson. Besarnya nilai korelasi biasa disebut dengan koefisien korelasi yang dinyatakan dalam lambang $r$ [19].

Sementara itu, koefisien korelasi adalah suatu angka yang menunjukkan derajat hubungan antara dua variabel. Besar dari koefisien ini adalah diantara +1 dan -1 . Koefisien relasi yang umumnya digunakan adalah koefisien Pearson.

Tabel 6. Interpretasi koefisien relasi.

\begin{tabular}{cl}
\hline$r$ & \multicolumn{1}{c}{ Tingkat Hubungan } \\
\hline 1 & Sempurna \\
$0,81-0,99$ & Sangat Kuat \\
$0,61-0,80$ & Kuat \\
$0,41-0,60$ & Sedang \\
$0,21-0,40$ & Rendah \\
$0,01-0,20$ & Sangat Rendah \\
0 & Tidak ada \\
\hline
\end{tabular}

Tabel 6 memberikan interpretasi koefisien relasi. Hubungan yang "Sempurna" bermakna dua variabel yang terkait adalah mempunyai hubungan yang sempurna, yang saling mempengaruhi. Nilai $r$ yang semakin mendekati 1 menunjukkan hubungan yang terjadi semakin kuat, sebaliknya jika semakin mendekati 0 [20].

Sedangkan uji reliabilitas digunakan untuk melihat keakuratan terhadap pengukuran yang dilakukan. Alat pengujiannya yaitu dengan mencari nilai koefisien Cronbach's Alpha.

Kemudian dilakukan analisa statistika deskriptif. Statistika deskriptif dilakukan dengan menggunakan distribusi frekuensi. Tujuannya agar mendapat gambaran ringkas dari sekelompok data dalam suatu tabel frekuensi.

Statistika deskriptif adalah cabang ilmu statistika yang mempelajari tentang cara pengumpulan dan pengolahan data menjadi informasi yang bermanfaat dan lebih menarik serta penyajiannya sedemikian rupa sehingga mudah dimengerti. Informasi yang diperoleh dari analisis statistika deskriptif antara lain adalah pemusatan data (mean, median, dan 
modus), penyebaran data (standar deviasi, varian, range) dan kecenderungan sekelompok data.

Hasil statistika dekriptif adalah sebagaimana yang ditunjukkan pada Tabel 7 . Distribusi frekuensi setiap pilihan jawaban diambil rata-ratanya untuk empat kelas pertanyaan tersebut. Kelas I tidak diikutkan dalam uji statistika deskriptif ini dengan alasan data pada kelas tersebut adalah identitas dari responden dan tidak ada pertanyaan yang berkaitan dengan penggunaan internet.

Tabel 1. Statistika deksriptif dari rata-rata setiap kelas pertanyaan.

\begin{tabular}{lccccc}
\hline & SS & S & N & TS & STS \\
\hline Kelas & $28.18 \%$ & $42.12 \%$ & $22.42 \%$ & $4.55 \%$ & $2.73 \%$ \\
II & & & & & \\
Kelas & $29.29 \%$ & $44.44 \%$ & $18.18 \%$ & $5.56 \%$ & $2.53 \%$ \\
$\begin{array}{l}\text { III } \\
\text { Kelas }\end{array}$ & $17.13 \%$ & $38.11 \%$ & $28.44 \%$ & $13.40 \%$ & $2.91 \%$ \\
IV & & & & & \\
$\begin{array}{l}\text { Kelas } \\
\text { V }\end{array}$ & $31.70 \%$ & $33.80 \%$ & $26.34 \%$ & $6.88 \%$ & $1.28 \%$ \\
\hline
\end{tabular}

Berdasarkan hasil tersebut, keempat kelas pertanyaan memiliki frekuensi tertinggi pada rata-rata dari pilihan jawaban Setuju. Hasil ini memberikan dasar yang kuat pada kami untuk menyatakan bahwa hampir lima puluh persen responden setuju dengan gambaran diri mengenai manfaat penggunan internet, gambaran diri mengenai kemudahan yang diperoleh dari penggunaan internet, perilaku terkait penggunaan internet, dan tujuan dari penggunaan internet.

Untuk kelas pertanyaan II dan III, butirbutir pertanyaan berkaitan dengan persepsi atau gambaran diri sivitas akademika UIN Sunan Kalijaga mengenai manfaat internet dan kemudahan yang didapat dari menggunakan internet. Dalam hal ini objek/stimulus adalah fasilitas Wi-Fi di UIN Sunan Kalijaga yang membentuk respon sivitas akademika UIN Sunan Kalijaga. Respon ini kemudian membentuk persepsi yang hendak diukur dalam penelitian ini [21]. Hasil pengukuran kedua persepsi adalah cukup bagus yaitu hampir setengah dari responden memperoleh persepsi yang positif.

Sementara itu, untuk kelas pertanyaan IV berkaitan dengan perilaku sivitas akademika UIN Sunan Kalijaga dalam menggunakan internet. Berdasarkan Pirolli yang dirujuk oleh [22], manusia secara adaptif membentuk perilakunya berdasarkan lingkungan informasinya, demikian sebaliknya yaitu lingkungan informasi dibentuk oleh manusia. Dalam hal ini lingkungan informasi di UIN Sunan Kalijaga.

Untuk kelas pertanyaan V (tujuan dari penggunaan internet), bisa disimpulkan bahwa sejumlah $33.80 \%$ sivitas akademika UIN Sunan Kalijaga terkategori heavy users dalam penggunaan internet. Hal ini berdasarkan kategori yang diberikan oleh The Graphic, Visualizaton \& Usability Center, The Georgia Institute of Technology yang dikutip di dalam [22].

Beberapa hal yang bisa mendasari hasil tersebut adalah kualitas layanan internet di UIN Sunan Kalijaga masih dalam kategori sedang, seperti hasil penelitian Mahardhika [23], Wishnu [24]. Mahardhika menemukan bahwa kualitas jaringan Wi-Fi di Fakultas Sains dan Teknologi, UIN Sunan Kalijaga masih belum maksimal, dengan delay sebesar 159 milidetik, throughput $9.0 \mathrm{Mbps}$ (50\%), dan packet loss ratio $36 \%$ dari pengukuran menggunakan standar TIPHON. Wishnu menemukan hasil yang tidak jauh berbeda dari penelitian Mahardhika yaitu pada video dengan kualitas 480p, menghasilkan delay 20 milidetik, level kualitas jitter -0.0269 , throughput $0.55 \mathrm{Mbps}$ (3\%), dan nilai packet loss $28 \%$.

Sebagaimana disampaikan sebelumnya, penelitian ini memiliki dua hipotesis yang hendak dibuktikan. Untuk keperluan ini, kami menguji masing-masing hipotesis dengan menggunakan analisis korelasi sederhana. Untuk pengujian ini kami tentukan nilai signifikansi adalah 0.05. Sehingga suatu hipotesis akan diterima jika nilai signifikasi adalah kurang dari 0.05. Kami berikan analisa per hipotesis sebagaimana ditunjukkan pada Tabel 8.

Tabel 2. Pengujian korelasi untuk hipotesis pertama.

\begin{tabular}{|c|c|c|c|}
\hline & & $\begin{array}{l}\text { Pengetahuan } \\
\text { mengenai } \\
\text { Eduroam }\end{array}$ & $\begin{array}{c}\text { Keinginan } \\
\text { bergabung } \\
\text { dengan } \\
\text { Eduroam }\end{array}$ \\
\hline \multirow{3}{*}{$\begin{array}{l}\text { Pengetahuan } \\
\text { mengenai } \\
\text { Eduroam }\end{array}$} & $\begin{array}{l}\text { Pearson } \\
\text { Correlation }\end{array}$ & 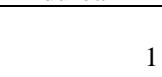 &, $724(* *)$ \\
\hline & $\begin{array}{l}\text { Sig. (2- } \\
\text { tailed) }\end{array}$ & & ,000 \\
\hline & $\mathrm{N}$ & 66 & 66 \\
\hline \multirow{2}{*}{$\begin{array}{l}\text { Keinginan } \\
\text { bergabung } \\
\text { dengan } \\
\text { Eduroam }\end{array}$} & $\begin{array}{l}\text { Pearson } \\
\text { Correlation }\end{array}$ &, $724(* *)$ & 1 \\
\hline & $\begin{array}{l}\text { Sig. (2- } \\
\text { tailed) }\end{array}$ & ,000 & \\
\hline
\end{tabular}




\begin{tabular}{l}
\hline N \\
\hline Tabel 8 menunjukkan pengujian korelasi \\
untuk hipotesis pertama. Dari hasil analisis \\
korelasi sederhana didapat koefisien korelasi \\
antara pengetahuan mengenai Eduroam dengan \\
keinginan bergabung dengan jaringan Eduroam \\
adalah 0.724. Hal ini menunjukkan bahwa \\
terjadi hubungan yang kuat antara pengetahuan \\
mengenai Eduroam dengan keinginan \\
bergabung dengan jaringan Eduroam \\
(perhatikan Tabel 6). Adapun arah hubungan \\
adalah positif karena nilai $r$ positif, berarti \\
semakin tinggi pengetahuan mengenai \\
Eduroam maka semakin meningkatkan \\
keinginan bergabung dengan jaringan \\
Eduroam. Nilai signifikansi yang kurang dari \\
0.05 (dalam kasus ini adalah 0.000) \\
menandakan bahwa hipotesis pertama dapat \\
diterima. Kesimpulannya adalah ada hubungan \\
yang positif antara pengetahuan mengenai \\
Eduroam dengan keinginan bergabung dengan \\
jaringan Eduroam. Sementara itu, dari \\
pengujian analisis hipotesis kedua diperoleh \\
informasi seperti yang ditunjukkan pada Tabel \\
$9 . \quad$ a
\end{tabular}

Tabel 3. Pengujian korelasi untuk hipotesis kedua.

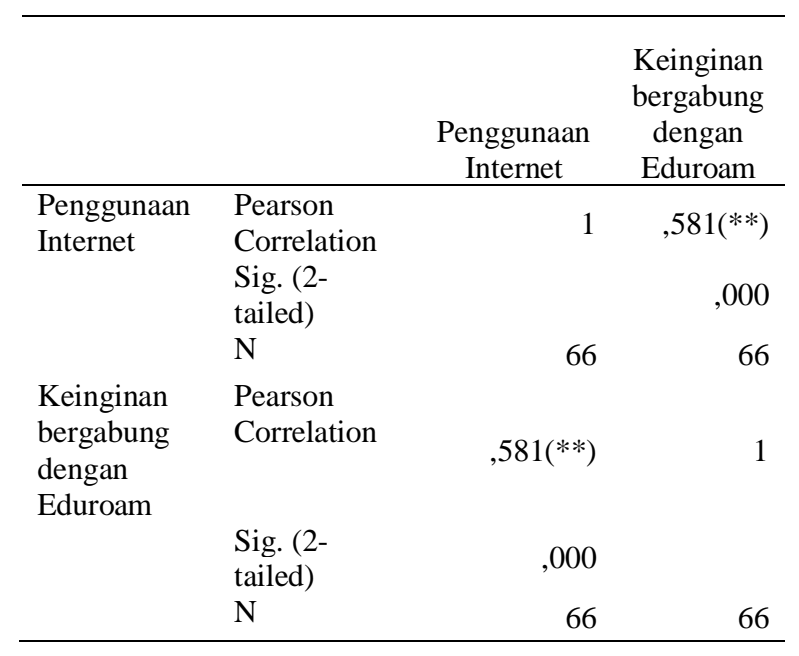

Dari hasil analisis korelasi sederhana didapat koefisien korelasi antara penggunaan internet dengan keinginan bergabung dengan jaringan Eduroam adalah 0.581. Hal ini menunjukkan bahwa terjadi hubungan yang kuat antara penggunaan internet dengan keinginan bergabung dengan jaringan Eduroam. Adapun arah hubungan adalah positif karena nilai $r$ positif, berarti semakin tinggi penggunaan internet maka semakin meningkatkan keinginan bergabung dengan jaringan Eduroam.

\section{PENUTUP}

Berdasarkan uraian di bab sebelumnya, penelitian kami berhasil menunjukkan hubungan antara pengetahuan mengenai Eduroam dengan keinginan untuk bergabung dengan Eduroam dan hubungan antara penggunaan internet dengan keinginan untuk bergabung dengan Eduroam. Koefisien korelasi yang nilainya berada pada interval Kuat dari Tabel 6 dan nilai $r$ yang positif serta nilainya lebih kecil dari nilai signifikasi yang ditetapkan sebagai dasar bagi kami dalam menunjukkan kedua hipotesis kami. Sehingga kami menyimpulkan Eduroam layak untuk diimplementasikan di UIN Sunan Kalijaga, tetapi sebelumnya perlu ditingkatkan kualitas dan kuantitas dari fasilitas koneksi internet di UIN Sunan Kalijaga. Sejalan dengan penelitian kami ini, pihak terkait dengan pengelolaan teknologi informasi dan pangkalan data di UIN Sunan Kalijaga, dalam hal ini adalah PTIPD (Pusat Teknologi Informasi dan Pangkalan Data) telah mengikuti pelatihan-pelatihan dan diskusi-diskudi terkait Eduroam beberapa bulan terakhir. Selain itu, ke depannya, penelitian ini bisa dilanjutkan dengan menambah jumlah responden sehingga lebih representatif mewakili jumlah sivitas akademika di UIN Sunan Kalijaga.

\section{DAFTAR PUSTAKA}

[1] "Eduroam." [Online]. Available: https://www.eduroam.org/.

[2] "UII Gelar Workshop FreeRadius." [Online]. Available: https://www.eduroam.org/.

[3] Y. N. Kunang, T. Ibadi, and Suryayusra, "Celah Keamanan Sistem Autentikasi Wireless Berbasis RADIUS," Semin. Nas. Apl. Teknol. Inf., vol. 34, no. 2, pp. 1907-5022, 2013.

[4] "Eduroam Ilmu Komputer 1801 mint.senior.web.id." [Online]. Available: http://mint.senior.web.id/IT/1801-

1697/eduroam_1738_mintsenior.html\#cite_ref-3.

[5] A. R. Adisti and H. Heriyanto, "Hubungan Pemanfaatan Teknologi WiFi Dengan Tingkat Kunjungan Pemustaka Di UPT Perpustakaan 
Politeknik Negeri Semarang," J. Ilmu Perpust., vol. 1, no. 1, pp. 60-66, 2012.

[6] C. K. Langsa, "Penggunaan Fasilitas Wifi..........Jelita 110," pp. 110-120.

[7] L. A. K. Wardani, Murahartawaty, and L. Ramadani, "Perancangan Tata Kelola Layanan Teknologi Informasi Menggunakan ITIL versi 3 Domain Service Transition Dan Service Operation Di Pemerintah Kota Bandung," J. Inf. Syst. Eng. Bus. Intell., vol. 2, no. 2, pp. 81-87, 2016.

[8] "Eduroam Indonesia." [Online]. Available: https://eduroam.id/.

[9] T. Indonesia, "Layanan WiFi (Wireless Fidelity) sekarang."

[10] P. Lai, "the Literature Review of Technology Adoption Models and Theories for the Novelty Technology," $J$. Inf. Syst. Technol. Manag., vol. 14, no. 1, pp. 21-38, 2017.

[11] F. D. Davis, R. P. Bagozzi, and P. R. Warshaw, "User Acceptance of Computer Technology: A Comparison of Two Theoretical Models," informsPubsOnline, vol. 35, no. 8, 1989.

[12] R. S. Dewi, A. H. N. Ali, M. Astuti, A. I. Pengajaran, and D. Ipd, "Analisis Pengaruh Kualitas Informasi pada Kuesioner Indeks Pengajaran Dosen Online terhadap Kepuasan Pengguna Studi Kasus: Fakultas Teknologi Informasi ITS," Tek. ITS, vol. 1, no. 1, p. A-345-A351, 2012.

[13] D. Nurhidayat, "Kuesioner Penelitian Survei Model Penerimaan User Terhadap Teknologi WiFi/Hotspot Publik pada Civitas Akademika Universitas XYZ," 2008.

[14] L. Purwanto, T. D.-J. J. Informatika, and undefined 2018, "Pengukuran Tingkat Kematangan Tata Kelola Pengelolaan Permasalahan Sistem Informasi Menggunakan Kerangka Kerja COBIT 4.1 (Studi Kasus: Sistem Informasi," Jurnalnasional.Ump.Ac.Id, vol. 1, 2017.

[15] H. Usman and N. Sobari, Aplikasi teknik multivariate untuk riset pemasaran. 2013.

[16] Suparto, "Analisis Korelasi VariabelVariabel yang Mempengaruhi Siswa dalam Memilih Perguruan Tinggi," IPTEK, vol. 18, no. 2, 2014.

[17] L. Kholisoh, "Statistika Probabilitas.pdf." 2017.
[18] H. Prastyo, Statistik Dasar: Sebuah Panduan untuk Peneliti Pemula, no. May. 2017.

[19] H. Usman and P. S. Akbar, Pengantar statistika. 2006.

[20] S. B. Nugroho, D. Nugroho, and Kustanto, "Korelasi Antara Prestasi Akademik dengan Tingkat Kemampuan TIK pada Sekolah Dasar Negeri 3 Malangjiwan," TIKomSiN, vol. 2, no. 2, 2014.

[21] Nawawi, "Persepsi Mahasiswa Menggunakan Fasilitas Wi-Fi Dalam Mencari Informasi Di Kalangan Mahasiswa Fakultas Ilmu Sosial Dan Ilmu Politik Universitas Riau," JOM FISIP Vol. 4 No. 2 - Oktober 2017 Page 1, vol. 4, no. 1, pp. 1-14, 2017.

[22] I. Novianto, "Perilaku Penggunaan Internet di Kalangan Mahasiswa," $J$. Univ. Airlangga, vol. 2, no. 1, pp. 1-40, 2013.

[23] Y. B. Mahardhika, "Analisis Quality of Service Jaringan Wireless SUKANET WiFi di Fakultas Sains dan Teknologi UIN Sunan Kalijaga,” 2017.

[24] A. Wishnu and B. Sugiantoro, "Analysis of Qaulity of Service (QoS) Youtube Streaming Video Service in Wireless Network in the Environment Faculty of Science and Technology UIN Sunan Kalijaga," IJID, vol. 7, no. 2, pp. 30-35, 2018.

\section{UCAPAN TERIMA KASIH}

Penulis mengucapakan terima kasih sebesar-besarnya kepada LPPM UIN Sunan Kalijaga yang telah menyediakan dana bagi penelitian kami ini. Penulis juga mengucapkan terima kasih kepada kolega kami di Prodi Matematika, Fakultas Sains dan Teknologi, UIN Sunan Kalijaga, khususnya ibu Epha Diana Supandi yang bersedia meluangkan waktunya untuk berdiskusi mengenai statistik.

\section{Hak Cipta}

Semua naskah yang tidak diterbitkan, dapat dikirimkan di tempat lain. Penulis bertanggung jawab atas ijin publikasi atau pengakuan gambar, tabel dan bilangan dalam naskah yang dikirimkannya. Naskah bukanlah naskah jiplakan dan tidak melanggar hak-hak lain dari 
pihak ketiga. Penulis setuju bahwa keputusan untuk menerbitkan atau tidak menerbitkan naskah dalam jurnal yang dikirimkan penulis, adalah sepenuhnya hak Pengelola. Sebelum penerimaan terakhir naskah, penulis diharuskan menegaskan secara tertulis, bahwa tulisan yang dikirimkan merupakan hak cipta penulis dan menugaskan hak cipta ini pada pengelola. 